\title{
Healthy Environments or High Prices? Residents' Perspective to the Urban Regeneration Projects in Atasehir, Istanbul
}

\author{
Deniz Erdem Okumus, Engin E. Eyuboglu* \\ Urban and Regional Planning Department, Faculty of Architecture, Istanbul Technical University (ITU), Istanbul, Turkey \\ Email: deniz.erdm@gmail.com, *engin.eyuboglu@gmail.com
}

How to cite this paper: Okumus, D. E., \& Eyuboglu, E. E. (2017). Healthy Environments or High Prices? Residents' Perspective to the Urban Regeneration Projects in Atasehir, Istanbul. Current Urban Studies, 5, 444-465.

https://doi.org/10.4236/cus.2017.54025

Received: June 8, 2017

Accepted: December 4, 2017

Published: December 7, 2017

Copyright $\odot 2017$ by authors and Scientific Research Publishing Inc. This work is licensed under the Creative Commons Attribution International License (CC BY 4.0).

http://creativecommons.org/licenses/by/4.0/

\section{(c) (i) Open Access}

\begin{abstract}
Regeneration movement is an irreplaceable necessity for Istanbul not only to prevent the destructions of earthquake and improve physical quality, but also to enhance the quality of life, reduce social vulnerability and maintain both social and physical sustainability. In Turkey, the term of urban regeneration has had different descriptions according to various agencies and stakeholders since 1980s. While academicians evaluate the regeneration projects as planning tools for having sustainable and high quality urban environments from social, ecological and economic approaches, investors for instance justify that they need more development rights and need to make more money to build good condition buildings for having that kind of neighborhoods. Residents, however, are the most important stakeholders to decide the future of the neighborhood. This research aims to evaluate what the residents' satisfaction level, perceptions and expectations are about the conditions and the possible urban regeneration movements in the neighborhood. 5 main headings are specified as main indicators for the research and conducted by surveys and interviews with current residents in the case of Atasehir, Barbaros Neighborhood which is a new developing and attractive area for real estate investments and urban regeneration projects in Istanbul. At the end of this research, it is stated that residents are very aware of the content of urban regeneration at practice level, and they believe in their neighborhood needs to regenerate for several reasons. They, however, discredit the term about having environment which is healthy and has high quality of life. They are just interested in the economic returns of the projects, and they expect to be built high level income housing to sell the prices out of the market.
\end{abstract}

\section{Keywords}

Urban Regeneration, Residents Perception, Satisfaction, Expectation, Atasehir, Barbaros 


\section{Introduction}

Roberts defines urban regeneration as a comprehensive and integrated process for solving social, economic and environmental problems of urban areas (Roberts, 2000). It is, also, in a relation with creating employment opportunities by investments and well-being of the society (Tsenkova, 2002; Osman, 2014). On the other hand, at an earlier date, while Lichfield (1992) identifies the term as a reconciliation to understand the disruption and the solution processes of urban environments, Donnison (1993) explained that urban regeneration consists of procedures and methods to solve problems in collapsed areas (Lichfield, 1992; Akkar, 2006).

Based on these definitions, urban regeneration can be stated as a term that contains local politics and strategies producing to fill the gaps caused by transformations, changes and improvements at every scale of urban environment. Therefore, it develops socially, environmentally, culturally and economically integrated strategies and projects (Okumus, 2014).

On the other hand, urban regeneration has to interfere the areas within the limits of urban development plan. Accordingly, it cannot be defined as a method for urban planning, and it must be used as an application tool of urban planning (Okumus, 2014).

Although for many years in the world especially after industrial revolution, urban regeneration has been used as a planning tool, in Turkey it has been interpreted in different scales and types expediently. Recently, urban regeneration has been seen as the way of "earthquake risk mitigation" in cities by demolishing risky buildings and constructing new ones since the coming into operation of law of 6306 in 2012. Although the main reasons like improving physical quality, reducing social vulnerability and maintaining both social and physical sustainability, the regeneration processes are disputable because of the inefficiency in participation of the residents of neighborhoods.

Residents are the most important stakeholders to decide the future of the neighborhood. Therefore, this research is very important to evaluate the residents' satisfaction level, perceptions and expectations are about the possible urban regeneration movements in the neighborhood.

In this part of research paper, evaluation of regeneration movements in Turkey is explained by years, and some case studies about residents' perceptions are examined.

\section{Disaster-Oriented Urban Regeneration Movements in Turkey}

Cities in Turkey have both similarities and differences with cities in developed countries because of economic, political, historical, cultural and social circumstances about urban regeneration (Aydınl, 2012). For example, while the main purpose of urban regeneration projects in developed countries, to make a city having high quality of life, an innovative and a safe place, in Turkey urban regeneration aims that making illegal buildings legal or rebuilding that places for earthquake mitigation (Sokmen, 2003). 
These urban regeneration movements are investigated in four periods in planning literature; 1950s, 1960-1970s, 1980-1990s and after 2000. However, since 2012, with the law of 6306, a new period has been defined in Turkey; "disaster-oriented urban regeneration movements".

After the Marmara Earthquake in 1999, urban regeneration plan and projects has been placed into law with 6306 by analyzing the earthquake resistance of existing buildings, and deciding some solutions. These solutions, however, have had different descriptions according to various agencies and stakeholders, for their purposes, eventually. Investors have tent to make more money over regeneration and requested more development rights. Local governments also have been using these movements to make profit and to make their cities or neighborhoods more attractive with new developing projects and new people.

According to this research, it is justified that residents are the most important stakeholders to decide the future of their neighborhood to sustain their lifestyle, habits and culture. According to Rogers, "culture gives meaning and pleasure to life, and urban regeneration, economic growth and cultural development are all interrelated" (Rogers, 1994). That's why this research aims to reveal their opinions, perceptions and expectations about the future of their neighborhood. There are six main research questions; "What is the meaning of urban regeneration from the residents' perspective?"; "What do they think about the effects of the projects on physical and social environment, social relationships and the residents' future?"; "Do they think their houses and neighborhood need to regenerate?"; "Are they satisfied with the surrounding projects?"; "What do they prefer to have in this neighborhood after regeneration?"; "Are they feeling hopeful for their neighborhood in future?"

\section{Methodology and Data}

In this research, three stages are adopted as a methodology; simplification and classification of indicators, collecting the qualitative data, and conversion them to the quantitative results. The stages can be checked up on Figure 1 as research design.

The first stage represents simplification and classification the indicators of research according to Figure 1. Table 1 shows that 39 indicators are classified under 5 main headings called demographic structure, housing conditions, satisfaction level, perception and expectation of residents. The demographic structure and housing conditions make it easier to understand the socioeconomic situation of residents by containing population, ages, education level, occupations etc. The answers of participants can be change according to their socioeconomic situation, therefore it is important to confirm the demography at first.

Indicators were adopted to a survey with 46 questions and interviews with participants conducting in April 2014, Atasehir Barbaros Neighborhood which is a potential area for urban regeneration. Table 2 shows 61 participants (housing units) and Table 3 shows 130 participants randomly selected for survey and 130 
Table 1. Indicators of research.

\begin{tabular}{ll}
\hline \multicolumn{1}{c}{ Main Headings } & \multicolumn{1}{c}{ Indicators } \\
\hline A1. Population of the House \\
A3. Ages of the Residents \\
A4. Cities of Birth of the Residents \\
A5. Education Level of the Residents \\
A6. Occupation of the Residents \\
A7. Time of Settlement in the Neighborhood \\
A8. The Reason for Living in the Neighborhood \\
A9. The Location Before Moving the Neighborhood \\
B1. The Number of the Rooms in the House \\
B2. The Situation of Restroom \\
B3. The Situation of Bathroom \\
B4. The Situation of Kitchen \\
B5. The Situation of Heating System \\
C1. Public Transportation System \\
C2. Frequency of Using Public Transportation \\
C3. Pedestrian Accessibility \\
C4. Vehicle Accessibility \\
C5. Accessibility to Social Urban Facilities \\
C6. Condition of House \\
C7. Condition of Neighborhood \\
C8. Willing to move from House \\
C9. Willing to move from Neighborhood \\
C10. Where to move \\
C11. Feeling about moving \\
C12. Sufficiency of Urban Facilities \\
\hline
\end{tabular}

D1. Knowing about Urban Regeneration

D2. Meaning of Urban Regeneration

D. Perception Of Residents

D3. Projects of Surrounding Area

D4. Using Facilities of Surrounding Projects

D5. Maintaining Living

E1. Necessity of Regeneration Project

E2. Actions to be Taken for Neighborhood

E3. Functions to be Had After Regeneration

E4. Dealing with Physical Problems

E. Expectation Of Residents

E5. Dealing with Social Problems

E6. Change of Neighborhood for Socially

E7. Real Estate Prices

E8. The Future of the Environment

5

39 


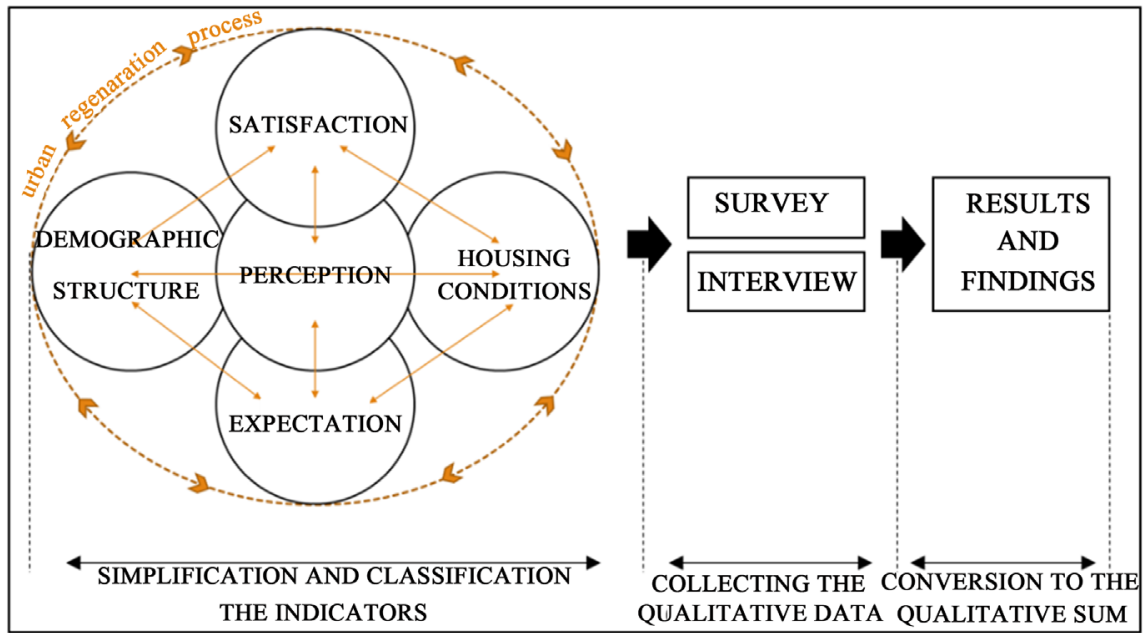

Figure 1. Research design.

Table 2. Sample number of survey.

\begin{tabular}{lc}
\hline Confidence Level & $90 \%$ \\
Confidence Interval & $10 \%$ \\
Total Housing Unit Number & 600 \\
Necessary Number of Sample & 61 \\
Performed Number of Sample & 61 \\
\hline
\end{tabular}

Table 3. Sample number for interview.

\begin{tabular}{lc}
\hline Confidence Level & $90 \%$ \\
Confidence Interval & $10 \%$ \\
Total Population of Neighborhood & 2520 people \\
Necessary Number of Sample & 66 \\
Performed Number of Sample & 130 \\
\hline
\end{tabular}

people for interview. Each survey and interview took 25 - 30 minutes at average. Survey contains of both closed and open-ended questions, and closed questions comprise answers in Likert Scale (1 - 5) and "yes-no" concept.

After defining the demographic structure and housing conditions, the satisfaction level of participants was asked by the questions about accessibility, sufficiency of social urban facilities, condition of house and neighborhood, and so on. Under the heading of perception level, participants' knowledge was asked about urban regeneration and surrounding projects, and at the end that the part of expectations, it was tried to understand what the current residents' physical, social and economic prospects for their neighborhood after a possible regeneration project (Table 1). 


\section{Step-By-Step to the Pressure of Urban Regeneration on Atasehir Barbaros Neighborhood}

The development process of Atasehir and Barbaros neighborhood is stated in this part of the paper by years. The rising of urban regeneration pressure on neighborhood is explained by the breaking points.

Atasehir is located on the Anatolian side of Istanbul and surrounded by the other counties called Maltepe, Kadikoy, Uskudar and Umraniye. It was a satellite town of Kadikoy at first, but it gained a position as a county in 2008. It has had 14 neighborhoods, and Barbaros is one of them. Its population reaches to 408.986 people according to 2014 data of TUIK. Figure 2 shows the " $\mathrm{O}_{2}$ " connection road of Bosphorus Bridge, dividing the county to 2 parts as West Atasehir and East Atasehir.

Although Atasehir was a satellite city project in 1990s, by the effects of globalization as well, it has become a focal point of investors and land developers in the concept of multi-storey residences and office buildings in recent years. And in 2012, urban regeneration movements started to take over the responsibility in the region, especially after the law of 6306. It is possible to say that urban growth process of Atasehir has prepared the county for urban regeneration in 6 stages/ periods: 1960-1970s, 1980s, 1990s, 2000s, 2012, after 2012 (Ozcelik, 2010).

The process began 1950s and 1960s with the industrialization, rapid urban growth and big migration from rural to big cities, especially to Istanbul. By the reason of insufficient housing stocks at that period, illegal housing areas and squatters appeared and started to develop the West Atasehir (Ozcelik, 2010).

Together with the laws of Illegal Housing (Anti-Squatting Law, 1984) and Mass Housing (Mass Housing Law, 1984) at 1984, whole illegal settlements had a master plan and gained legal status, and Atasehir began to develop in a planned way with Mass Housing Projects like "The project of Anatepe". This initiative of Illegal Housing Law led to expansion of multi-storey illegal settlements, and occurrence of ownership problems like multipartiteness that we are struggling to overcome currently (Okumus, 2014).

The third stage is formed by being a satellite city in 1995 and the Marmara Earthquake in 1999. After the earthquake, although many places in Istanbul was affected negatively, Atasehir interestingly became a focal point because of its earthquake-resistant structure geologically. In this period, Istanbul Metropolitan Municipality had some investments and plans, and doubled population (Erna, 2009). Moreover, land developers and investors had beady eye on Atasehir to build new real estates for high level income families. Therefore, land and house prices were increased depends on supply and demand equilibrium (Ozcelik, 2010).

As it is seen at Figure 3(a), constructions of three important projects were completed in 2008, and investments were maintained till 2012. During this period, the satellite Atasehir became a county (in 2008) independent from Kadikoy with the law of 5747. Along with being a county, Atasehir came into prominence as a new center of Istanbul (Figure 3(b)). 


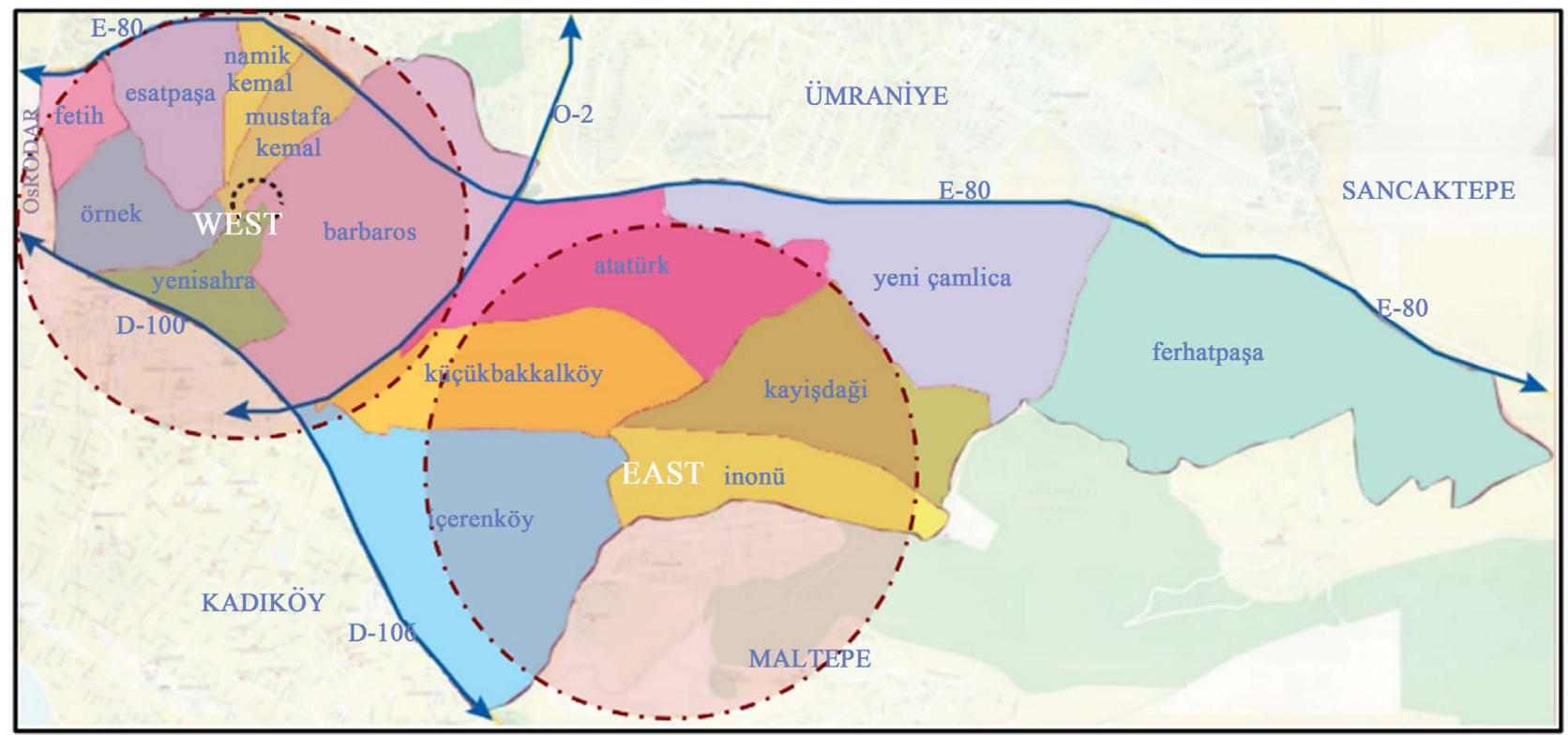

Figure 2. Atasehir County and 14 neighborhoods.

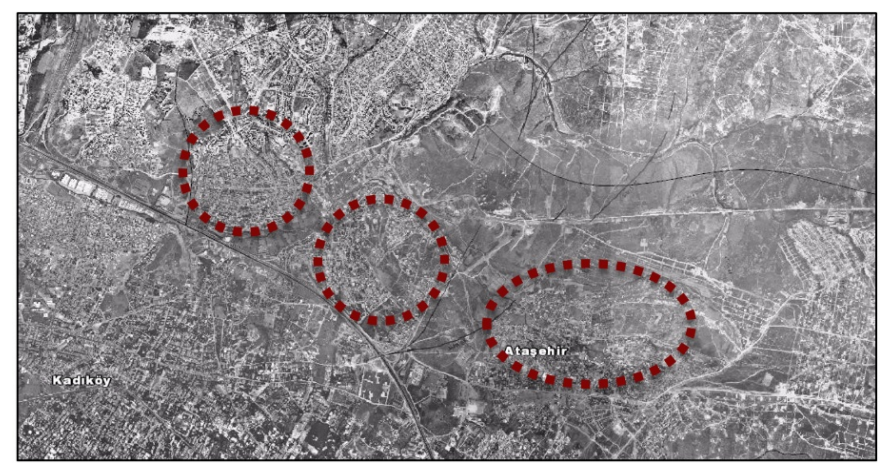

(a)

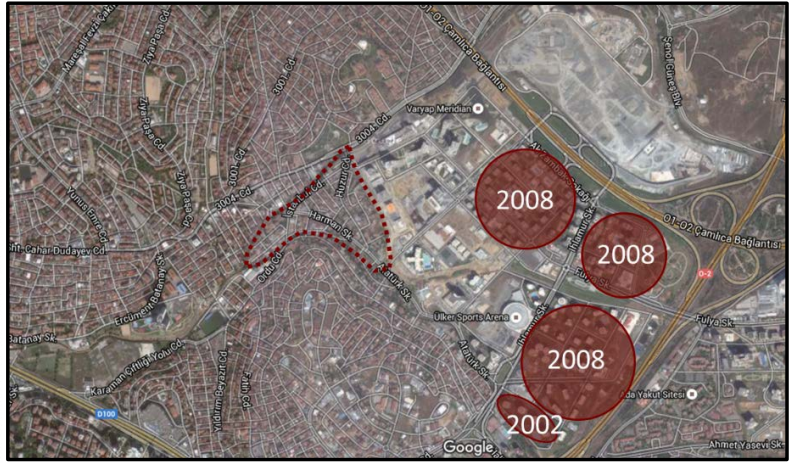

(b)

Figure 3. Satellite image of Atasehir in 1982 (URL-1). (b) Surrounding projects of Barbaros neighborhood.

As a matter of fact that, although Atasehir was not mentioned as any kind of center in 1/100.000 scale Master Plan of Istanbul in 1999, in the new Master Plan in 2009 , it was announced as $1^{\text {st }}$ degree national and international financial center in Figure 4.

According to the Figure 5, after the announcement of international financial center of Atasehir, investors and developers enlarged their working areas, and started new real estate projects. In the first quarter of 2012, three important projects were completed near the Barbaros Neighborhood.

All these projects were developed in partnership on empty areas with TOKI which is the representative authority of housing sector of Turkey. The real estate prices almost doubled again. Investors still had investment ambition, but they were in trouble to find large land for development. They had to turn their eyes on neighborhoods for urban regeneration, eventually.

In the second quarter of 2012, with the urban regeneration law of 6306 and its 


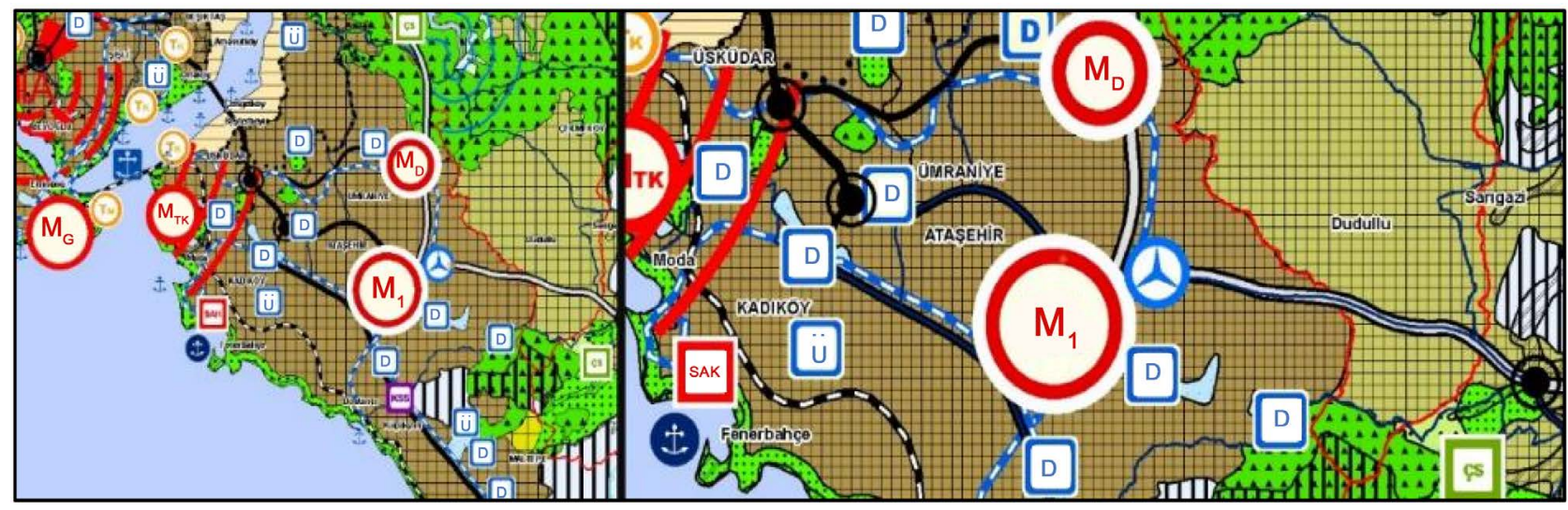

Figure 4. 1/100.000 scale master plan of Istanbul in 2009.

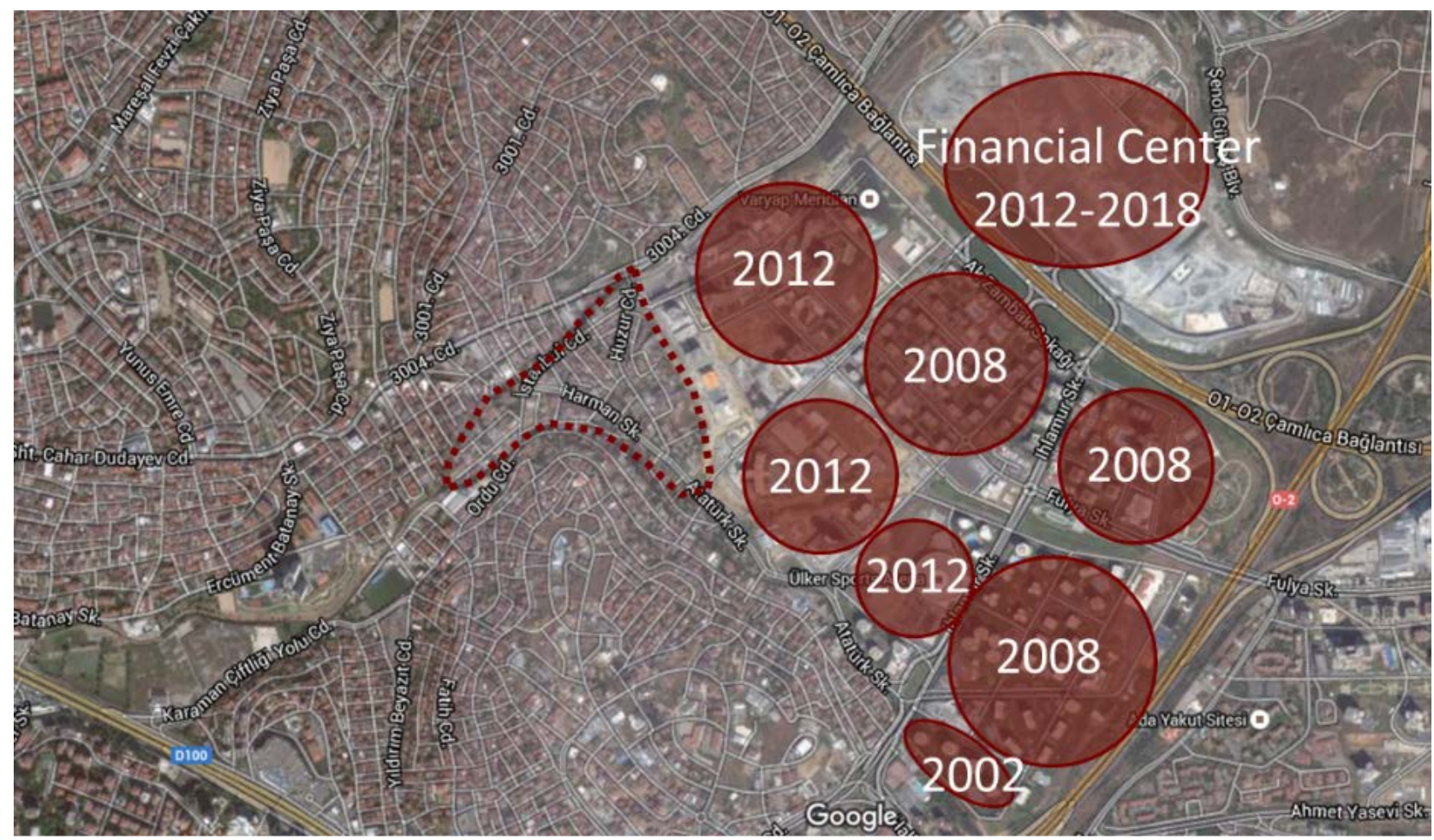

Figure 5. Surrounding projects of Barbaros neighborhood.

application regulations, urban regeneration movements increased in West Ata sehir. Figures 6-10 prove that Barbaros Neighborhood has been one of the popular area for regeneration as well, to produce more profitable real estate according to investors and land developers, beside the earthquake mitigation purpose. Although it has not defined as risky area by Ministry Of Environment And Urban Planning yet, the project designs and enterprises to conclude an agreement for regeneration have been still maintaining for 3 years. That was the first reason to be selected Barbaros Neighborhood as a case area for this research.

As it can be seen the development process of Atasehir, investors and land developers are like decision-makers for lands, neighborhoods or county. It is 
understandable that these stakeholders tend to build more profitable buildings, luxury residences and sell them good prices to make more money and to make more buildings. Urban regeneration can be a tool for that purpose. On the other

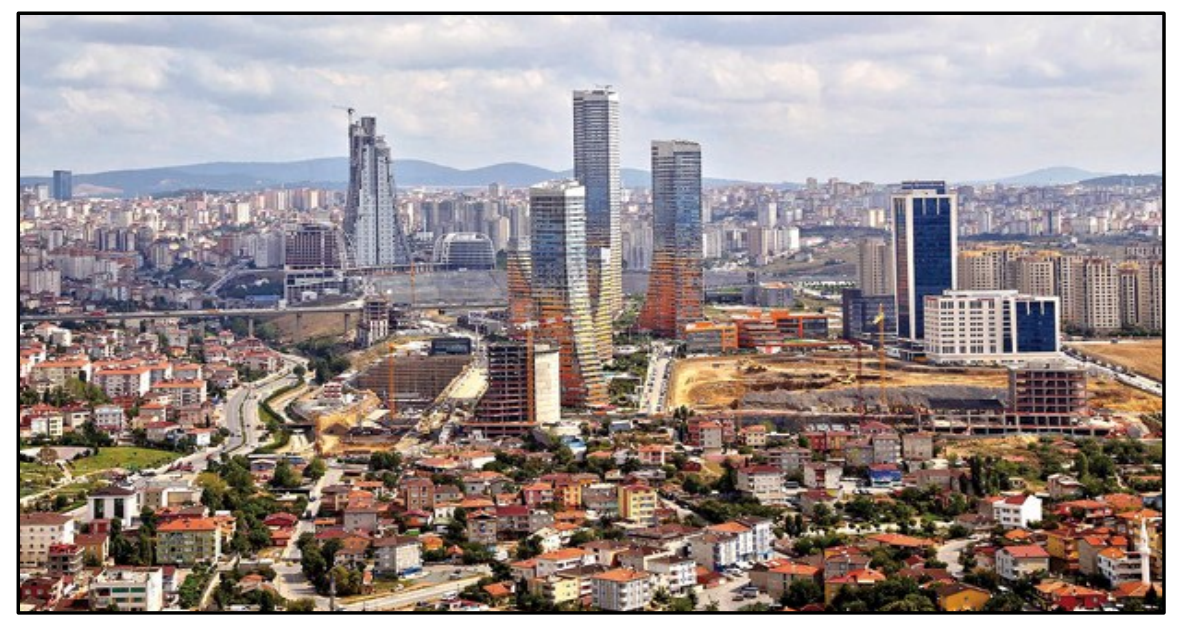

Figure 6. Surrounding projects and Barbaros Neighborhood (URL-2).

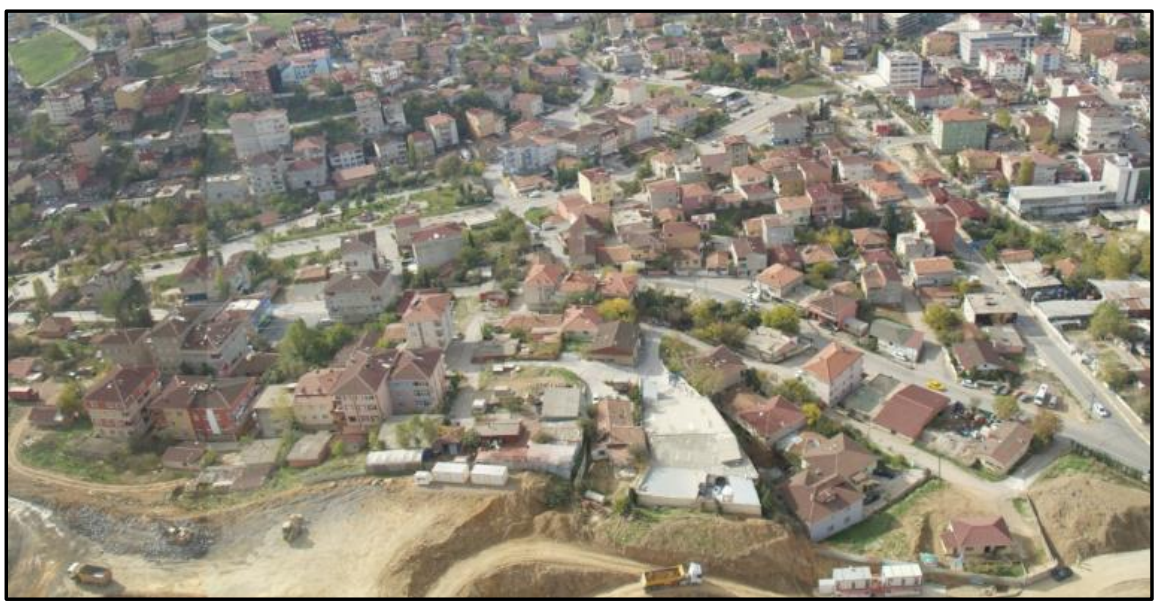

Figure 7. Barbaros neighborhood aerial viewpoint (Okumus, 2014).

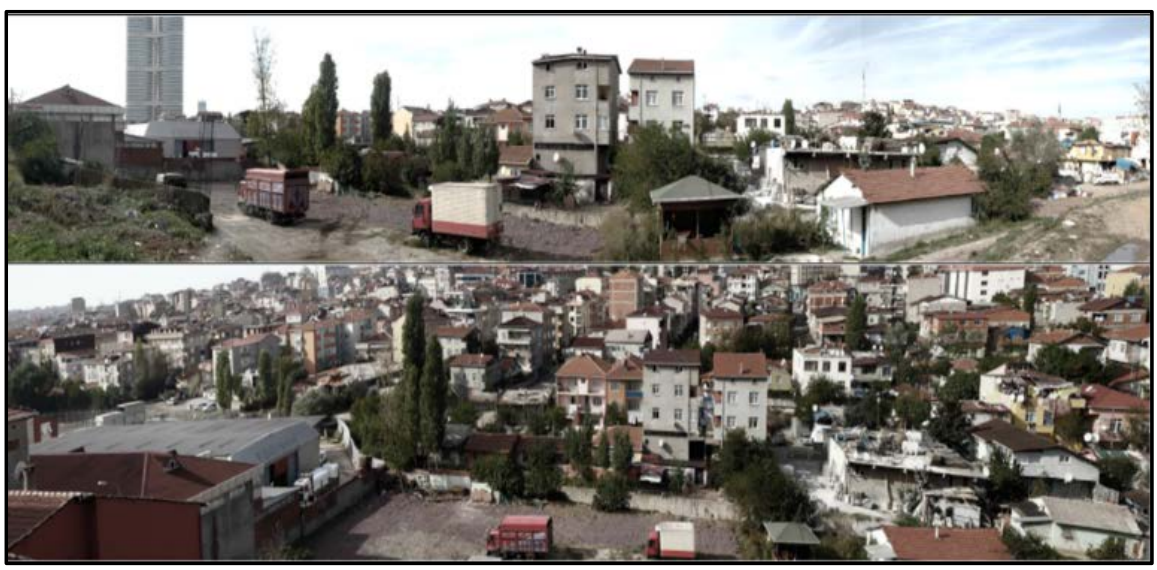

Figure 8. Barbaros neighborhood street View-1 (Okumus, 2014). 


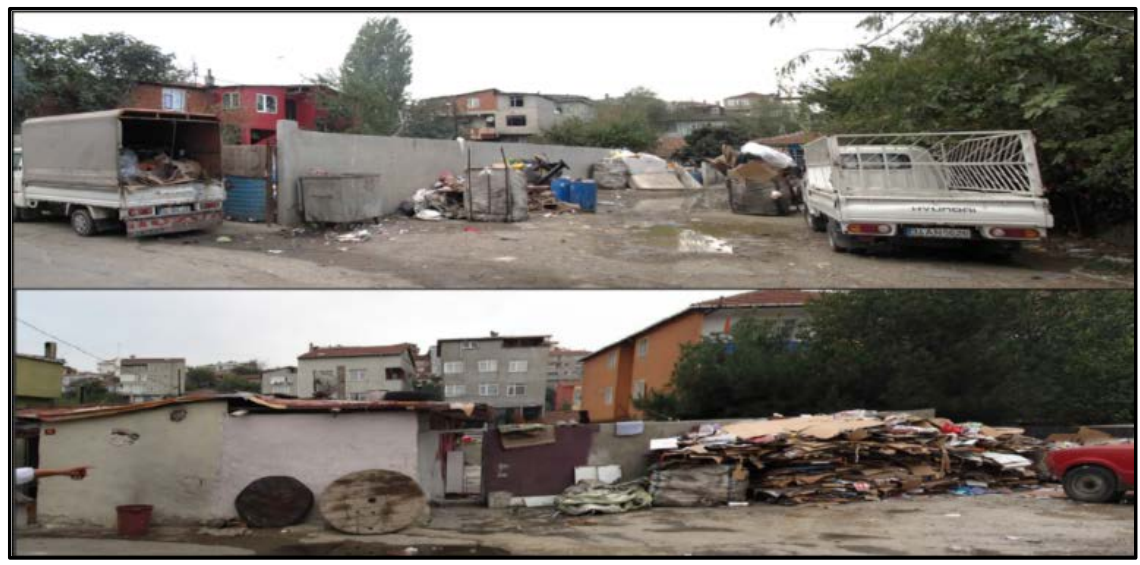

Figure 9. Barbaros neighborhood street view-2 (Okumus, 2014).

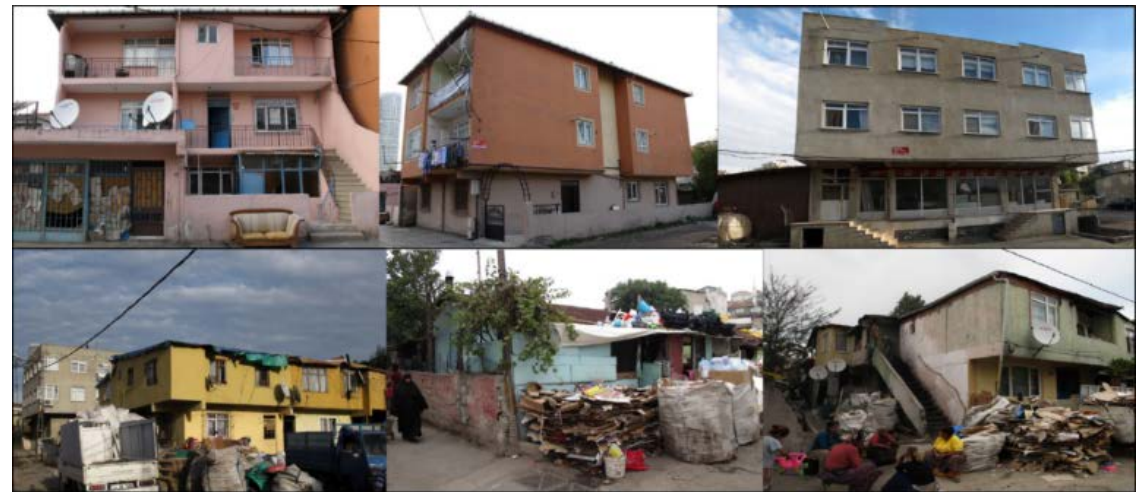

Figure 10. Barbaros neighborhood street view-3 (Okumus, 2014).

hand, new buildings in the city means good resistant for earthquakes from their perspective and they think they are killing two birds with one stone.

However, we all know that urban regeneration aims not only earthquake resistant or new buildings, it also focuses on producing more sustainable and high quality social and physical environments. And economic liveliness, as another purpose of regeneration, cannot be seen as an income channel. In the frame of regeneration, although current residents are the most important stakeholders to decide the future of their neighborhood, they have just 1 right; either accept the developer's project or reject the project.

In this research, it is stated that current residents should have something to say, and it was needed to ask them some questions which brightened the research way such as; "what do you think about regeneration and about your neighborhood?; "what do you need in this neighborhood?"; "are you satisfied?", and "what do you expect for the future?" shortly.

\section{Results and Findings of Research}

The third stage of research called "conversion qualitative data to the quantitative results" is explained, and the results and findings are interpreted in this part of paper. 


\subsection{Demographic Indicators}

The demographic structure and housing conditions make it easier to understand the socioeconomic situation of residents which are determinant factors for responses. Barbaros neighborhood, which has $127.000 \mathrm{~m}^{2}$ (12.7 ha) gross area, population is 2520 totally, and the population density is calculated around 200 person/ha in the area. Average household size is identified as 4.2 people. Generally people are between 17 - 35 ages, and the average of age is 31 in the area. $3 \%$ of participants is over the age of 65 .

On the other hand, the reflection of this age distribution to the education level seen in Graph 1(a) is 17\% percentage of pop. is under the primary school level, $41 \%$ is at the primary school level, $14 \%$ secondary school level, $15 \%$ is high school graduate, $6 \%$ is college graduate and the rest of pop. $8 \%$ is illiterate one.

The average time of settlement is 21 years. It was asked them by giving $5 \mathrm{op}-$ tions; "why did you prefer living here", $9 \%$ stated "closeness to work", $37 \%$ "low prices", 2\% "good condition of neighborhood", 37\% "relatives", and 15\% said "marriage" in Graph 1(b).

It is specified that most of people came from the Anatolian side of country by migration that process is stated in the $3^{\text {rd }}$ section of the paper. Although $49 \%$ of people were born in Istanbul, their parents came from Anatolian side, and the distribution of hometowns is like that 15\% Ordu, 10\% Ardahan, 5\% Kastamonu, 5\% Amasya, 5\% Kars. Figure 11 proves that they are interestingly located together as clusters on the land with their relatives.

According to Figure 11, the socioeconomic level declines from the $4^{\text {th }}$ part of the neighborhood to the $1^{\text {st }}$. In the $1^{\text {st }}$ area, Romany people, who are paper stackers to make money from recycling, are from Kastamonu and Amasya region. This area has the highest level of illiterate people. While the $2^{\text {nd }}$ area represents the people from Ordu region, people from Kahramanmaras locate in the $3^{\text {rd }}$ zone. And the last zone is $4^{\text {th }}$ does the honours of people from Kars and Ardahan. Although this zone has not only wealthier but also more educated people than the other zones, unemployment rate has the highest level in $4^{\text {th }}$ area. These features should have been effective on the answers of surveys.

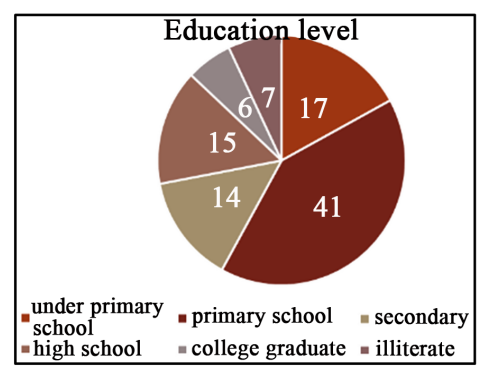

(a)

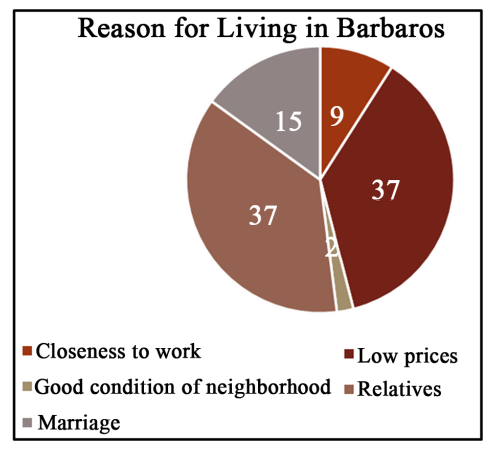

(b)

Graph 1. (a) Education level of Barbaros neighborhood; (b) Reasons for living in Barbaros neighborhood. 


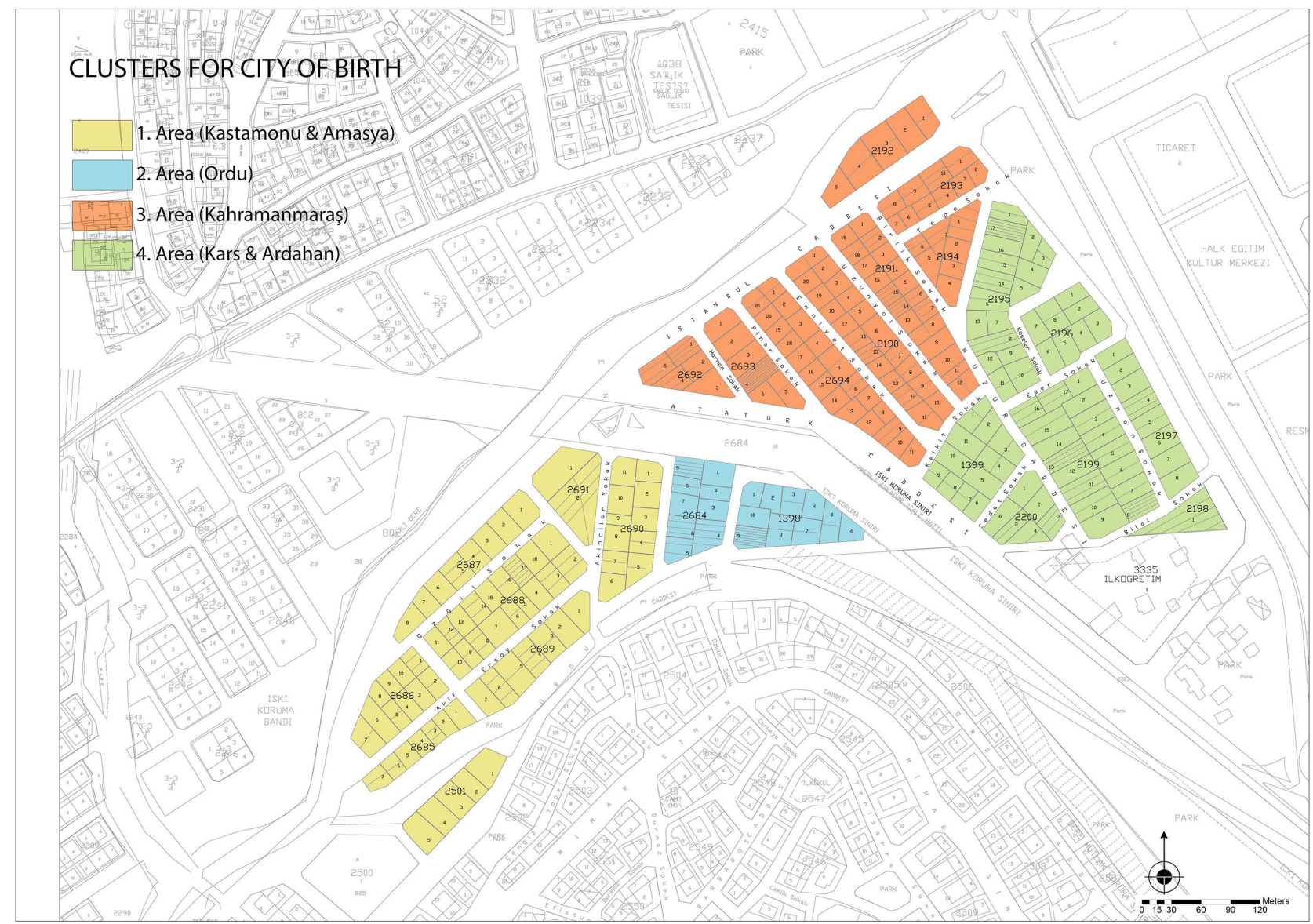

Figure 11. Hometown clusters in the research area.

\subsection{Housing Conditions}

There are 280 buildings in the area, and these buildings contain 600 housing units. 81 of these buildings and 121 of the housing units are illegal in the area. Moreover, according to the Municipality of Atasehir, the legal (the owners say so) buildings do not have any occupancy permit. Figure 12 shows the distribution of housing units and illegal buildings in the research area.

Houses have generally three rooms, one restroom, bathroom and kitchen inside. While $33 \%$ is using natural gas as a heating system, $67 \%$ of them is still using heating stove.

\subsection{Satisfaction Level}

Table 4 shows 12 indicators to understand the satisfaction level of current residents. Indicators are defined about public transportation system, frequency of using public transportation, pedestrian accessibility, vehicle accessibility, accessibility to social urban facilities, condition of house, condition of neighborhood, willing to move from house, willing to move from neighborhood, where to move, feeling about moving, and sufficiency about urban facilities. Some questions of indicators are gathered in Likert Scale (1 - 5), and some of them are 


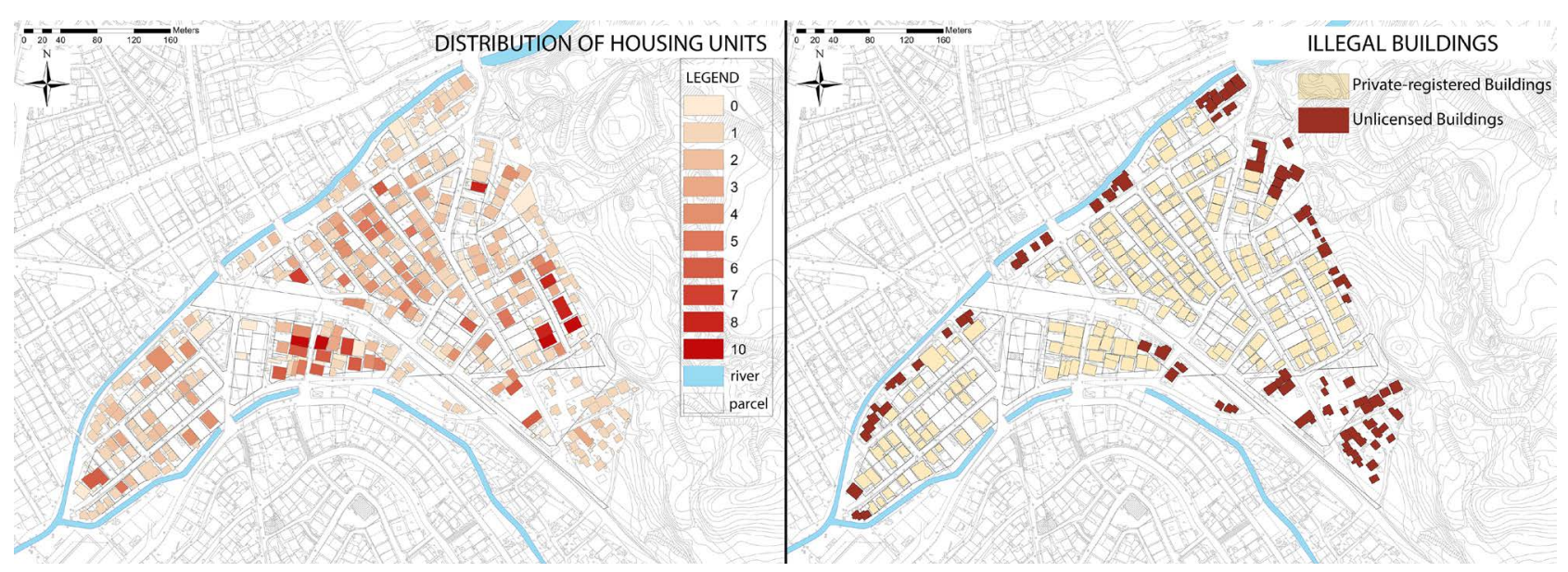

Figure 12. Distribution of housing units (left-handed), and illegal buildings distribution (right-handed).

Table 4. Indicators for satisfaction level, survey questions and types/scale of questions.

\begin{tabular}{|c|c|c|}
\hline Indicators & Questions & $\begin{array}{l}\text { Type/Scale } \\
\text { of Questions }\end{array}$ \\
\hline C1. Public transportation system & $\begin{array}{l}\text { What do you think about the } \\
\text { public transportation system? }\end{array}$ & Likert Scale (1 - 5) \\
\hline $\begin{array}{l}\text { C2. Frequency of using public } \\
\text { transportation }\end{array}$ & $\begin{array}{l}\text { How often do you use public } \\
\text { transportation system? }\end{array}$ & $\begin{array}{l}\text { Close-ended } \\
\text { Question }\end{array}$ \\
\hline C3. Pedestrian accessibility & $\begin{array}{c}\text { Are you satisfied with } \\
\text { pedestrian accessibility? }\end{array}$ & Likert Scale (1 - 5) \\
\hline C4. Vehicle accessibility & $\begin{array}{l}\text { Are you satisfied with } \\
\text { vehicle accessibility? }\end{array}$ & Likert Scale $(1-5)$ \\
\hline $\begin{array}{l}\text { C5. Accessibility to } \\
\text { social urban facilities }\end{array}$ & $\begin{array}{l}\text { Are you satisfied with } \\
\text { accessibility to urban facilities? }\end{array}$ & Likert Scale $(1-5)$ \\
\hline C6. Condition of house & $\begin{array}{l}\text { Are you satisfied } \\
\text { with your house? }\end{array}$ & Likert Scale (1 - 5) \\
\hline \multirow{5}{*}{ C7. Condition of neighborhood } & $\begin{array}{l}\text { Are you satisfied with } \\
\text { your neighborhood? }\end{array}$ & Likert Scale (1 - 5) \\
\hline & This is nice place to live & Likert Scale $(1-5)$ \\
\hline & The accessibility is easy to here & Likert Scale $(1-5)$ \\
\hline & Living condition is perfect here & Likert Scale (1 - 5) \\
\hline & This is a good place to raise a child & Likert Scale $(1-5)$ \\
\hline C8. Willing to move from house & $\begin{array}{l}\text { Do you think moving } \\
\text { from your house? }\end{array}$ & Yes-No Question \\
\hline $\begin{array}{l}\text { C9. Willing to move from } \\
\text { neighborhood }\end{array}$ & $\begin{array}{l}\text { Do you think moving } \\
\text { from this neighborhood? }\end{array}$ & Yes-No Question \\
\hline C10. Where to move & Where do you prefer to move? & $\begin{array}{l}\text { Open-ended } \\
\text { Question }\end{array}$ \\
\hline C11. Feeling about moving & $\begin{array}{l}\text { If you have to move, } \\
\text { do you feel sad? }\end{array}$ & Yes-No Question \\
\hline \multirow[t]{2}{*}{ C12. Sufficiency of urban facilities } & $\begin{array}{l}\text { Are you satisfied with the } \\
\text { sufficiency of urban facilities? }\end{array}$ & Likert Scale $(1-5)$ \\
\hline & $\begin{array}{l}\text { Can you select one of } \\
\text { them to represent your } \\
\text { Total satisfaction level? }\end{array}$ & Likert Scale $(1-5)$ \\
\hline
\end{tabular}


"yes-no" questions. In Likert Scale, the point of "1" shows the worst situation and the point of " 5 " shows the best situation in the research.

First of all, it was asked that what they think about the public transportation. They gave answers between 1 (very bad)-2 (bad)-3 (it's ok)-4 (good)-5 (very good). According to the responses, most of them (37\%) said it's "very bad". In interviews, they mentioned that public transportation is very infrequent and crowded.

When the frequency of using public transportation was asked by the question of "How often do you use public transportation?" just 13\% of them said "everyday"; and most of them (37\%) said "1 - 2 times a month" in Graph 2.

When we asked the satisfaction level about pedestrian accessibility, they mostly (59\%) gave the answer "very bad". They mentioned that they are afraid of walking in neighborhood because there is not any barrier or pavement for sidewalks, moreover, many streets do not have any sidewalks. Similarly, when we asked, "are you satisfied with accessibility to urban facilities?", they mostly (68\%) said "very bad" as well.

Secondly, we tried to understand the satisfaction level about condition of house and neighborhood. According to responses they mostly thought their houses (33\%) and neighborhood (28\%) are in "good" condition. Nevertheless, when we said "this is nice place to live", $30 \%$ is "certainly not agree"; "the accessibility s easy to here", $28 \%$ is "certainly not agree"; "living conditions is perfect here", $42 \%$ is "certainly not agree"; "this is a good place to raise a child", $76 \%$ is "certainly not agree" in Graph 3.

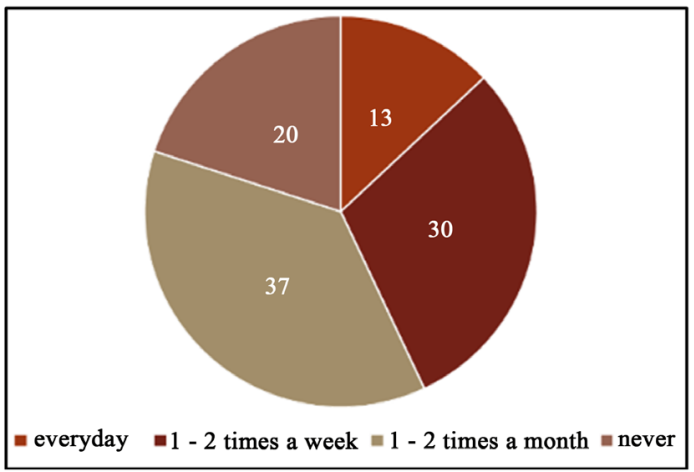

Graph 2. "How often do you use public transportation?".

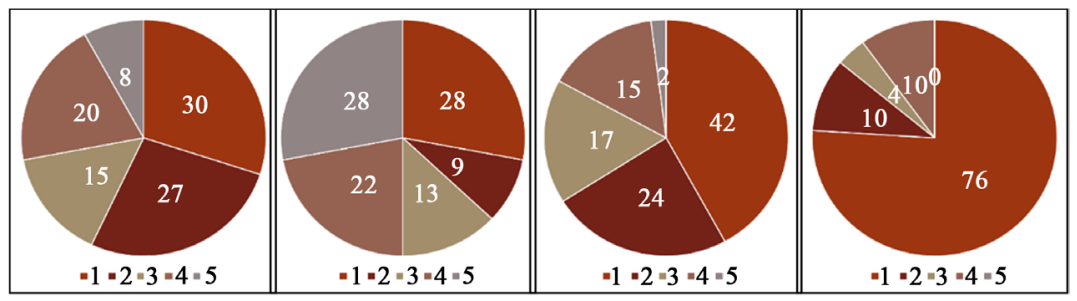

(a)

(b)

(c)

(d)

Graph 3. Responses for (a) This is nice place to live; (b) The accessibility s easy to here; (c) Living conditions is perfect here; (d) This is a good place to raise a child. 
Then we asked, "if so, do you think moving from your house?" and $60 \%$ said "yes". When we said "do you think moving from this neighborhood?", $70 \%$ of them said "no". Another question was "where do you prefer to go?". They gave the answers like "very close to this neighborhood", "to a better place", "another regeneration area", "to European side of Istanbul" and "to my hometown".

When we asked "If you have to move, do you feel sad?", on the contrary of previous responses, $60 \%$ of them said "no".

According to all these answers, there are 2 main points showing up from the responses to questions. Although during interviews, they complained about their housing conditions, they selected high points (mostly 4). However, they stated that they are willing to move from their houses. On the other hand, although they are generally not satisfied with public transportation, accessibility, urban facilities and the conditions of neighborhood, they stated that they do not want to move from neighborhood. However, they said that if they have to move, they would not feel sad.

Table 5 shows the percentages of responses, standard deviations and mean values for each indicator testing in Likert Scale. According to the table, it can be easily said that, pedestrian accessibility (c3) and accessibility to social urban facilities (c5) are very insufficient and more dissatisfied.

\subsection{Perceptions of Residents}

According to the Table 6, there are 5 indicators to understand the perceptions of current residents about urban regeneration, projects of surrounding area and maintaining living in neighborhood after a possible regeneration project.

Firstly, it was interrogated that knowing the meaning of urban regeneration. In Graph 4, 70\% of them said "yes" and gave the answers like "being developed of lands in exchange of an apartment by contractor"; "building new apartments

Table 5. Evaluation the indicators of satisfaction.

\begin{tabular}{ccccccccc}
\hline \multirow{2}{*}{ Indicators } & Mean Value & Standard Deviation & Skewness & \multicolumn{5}{c}{ Responses (\%) } \\
\cline { 5 - 9 } & & & & $\mathbf{1}$ & $\mathbf{2}$ & $\mathbf{3}$ & $\mathbf{4}$ & $\mathbf{5}$ \\
\hline $\mathrm{C} 1$ & 2.459 & 1.336 & 0.177 & 37 & 13 & 18 & 28 & 4 \\
$\mathrm{C} 3$ & 1.819 & 1.132 & 1.078 & 59 & 13 & 17 & 9 & 2 \\
$\mathrm{C} 4$ & 2.475 & 0.993 & 0.386 & 15 & 42 & 24 & 17 & 2 \\
C5 & 1.688 & 1.148 & 1.466 & 68 & 13 & 4 & 13 & 2 \\
C6 & 3.098 & 1.513 & -0.291 & 26 & 9 & 12 & 33 & 20 \\
C7-1 & 3.360 & 1.366 & -0.446 & 15 & 11 & 22 & 28 & 24 \\
C7-2 & 2.491 & 1.324 & 0.441 & 30 & 27 & 15 & 20 & 8 \\
C7-3 & 3.147 & 1.600 & -0.248 & 28 & 9 & 13 & 22 & 28 \\
C7-4 & 2.081 & 1.158 & 0.699 & 42 & 24 & 17 & 15 & 2 \\
C7-5 & 1.491 & 0.976 & 1.854 & 76 & 10 & 4 & 10 & 0 \\
C12 & 2.508 & 1.177 & 0.422 & 23 & 30 & 27 & 13 & 7 \\
\hline
\end{tabular}




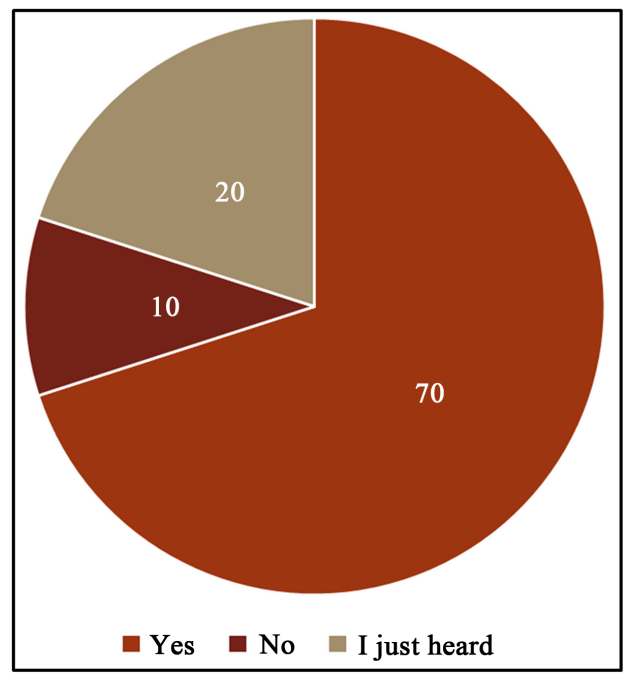

Graph 4. Responses for “do you know what urban regeneration means?”.

Table 6. Indicators for perceptions of residents, survey questions and question types.

\begin{tabular}{lcc}
\hline \multicolumn{1}{c}{ Indicators } & \multicolumn{1}{c}{ Questions } & Question Type \\
\hline $\begin{array}{l}\text { D1. Knowing About } \\
\text { Urban Regeneration }\end{array}$ & $\begin{array}{c}\text { Do you know what urban } \\
\text { regeneration means? }\end{array}$ & Yes-No Question \\
$\begin{array}{l}\text { D2. Meaning of Urban } \\
\text { Regeneration }\end{array}$ & $\begin{array}{c}\text { How do you define the } \\
\text { urban regeneration? }\end{array}$ & Open-ended Question \\
$\begin{array}{l}\text { D3. Projects of } \\
\text { Surrounding Area }\end{array}$ & $\begin{array}{c}\text { Are you satisfied with the projects } \\
\text { around your neighborhood? }\end{array}$ & Yes-No Question \\
$\begin{array}{l}\text { D4. Using Facilities of } \\
\text { Surrounding Area }\end{array}$ & $\begin{array}{c}\text { Do you use the facilities of these } \\
\text { projects around your neighborhood? }\end{array}$ & Yes-No Question \\
D5. Maintaining Living & $\begin{array}{l}\text { Do you think maintaining living here } \\
\text { after a possible regeneration project? }\end{array}$ & Yes-No Question \\
\hline
\end{tabular}

after destroying old ones"; "renovating and strengthening of buildings"; "reinforcing of buildings"; "developing of neighborhood"; "growing of neighborhood"; "more beautiful environment"; "more luxuorius buildings"; "destroying the illegal settlements and building new apartments with the contributions of government", and "newer buildings, higher prices" etc.

Then, it was asked that they are satisfied with the projects around their neighborhood or not. In Graph 5, 61\% of them said "no". Although participants, saying YES, justify that "high houses are the buildings of future", "the higher houses, the better prices"; participants, saying NO, justify that "these projects are not appropriate for our culture", "we cannot use these swimming pools while everybody is watching", "we cannot pay the dues of these projects", "they do not have neighborhood relations. If we die, nobody realizes", "we are used to spend time on streets". And they completely said "no" for the question of "do you use the facilities of these projects around your neighborhood?"

It was asked that they want to maintain living in this neighborhood after a possible regeneration project. 71\% of participants said "no" in Graph 6. Moreover, 


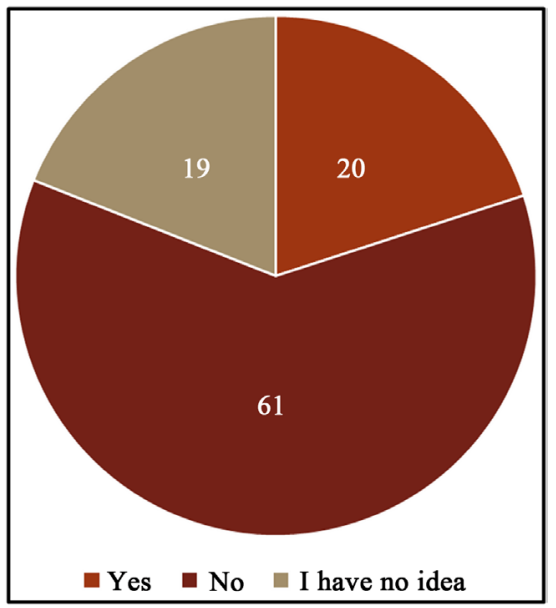

Graph 5. Responses for "are you satisfied with the projects around your neighborhood?".

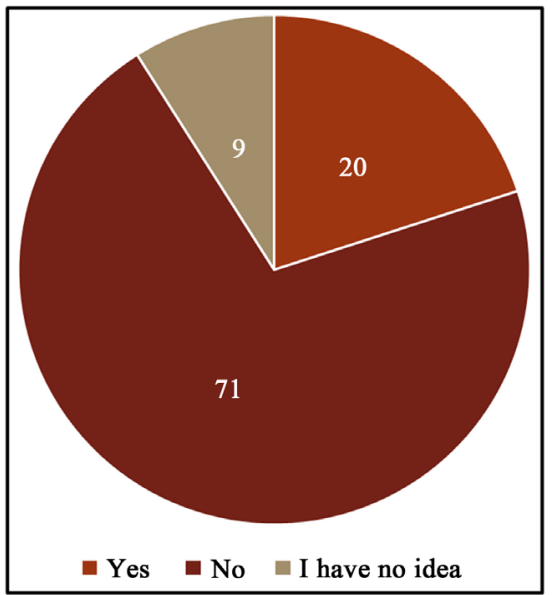

Graph 6. Responses for "do you think maintaining living here after a possible regeneration project?".

one of the participants said; "We are working in poultry husbandry and as a paper stacker. That's our lifestyle. We are not used to wear shoes. We are used to make barbecue. Rich people do not want to live with us. They shot the chickens down first, and then me. We will sell our apartments and settle down another area."

According to the responses, although they said they surely know the meaning of urban regeneration, they mostly gave market responses like "Destroying the illegal settlements and building new apartments with the contributions of government". It shows that people mostly interested in physical scale of urban regeneration. The second evaluation is that although they do not like the surrounding projects, and do not use their facilities, some people emphasizes that "The higher houses, the better prices". It shows that they are also interested in economic benefits of urban regeneration. And the responses show that, although they do not believe they can live in these kind of projects, they know they can sell their portion in good prices. 


\subsection{Expectations of Residents}

Table 7 shows that there are 8 indicators to understand the expectations of current residents for the future about a possible urban regeneration project in the neighborhood.

Firstly, it was examined that they think the urban regeneration is necessary for their neighborhood or not. The responses show that they mostly (89\%) believe in its necessity, and the rest of participants said "no" or "I have no idea".

Secondly, for the participants saying yes, the question of "what should be done to improve the conditions of neighborhood?" is asked, and they were responsible for four answers to select: 1) restore the old and unhealthy buildings and define them as dwelling or commercial functions; 2) demolish all buildings to build new ones; 3 ) demolish all old and unhealthy buildings to have parks, open spaces, and playgrounds; 4) any other options.

As it can be seen in Graph 7(a), 54\% of participants prefer demolishing all buildings to build new ones. Just $35 \%$ of them want to demolish all old and unhealthy buildings to have parks, open spaces and playgrounds, although they mostly criticize the sufficiency of these facilities in neighborhood in previous responses.

Table 7. Indicators for expectations of residents, survey questions and question types.

\begin{tabular}{|c|c|c|}
\hline Indicators & Questions & Question Type \\
\hline $\begin{array}{l}\text { E1. Necessity of } \\
\text { regeneration project }\end{array}$ & $\begin{array}{l}\text { Do you think that urban regeneration } \\
\text { is necessary for your neighborhood? }\end{array}$ & Yes-No Question \\
\hline $\begin{array}{l}\text { E2. Actions to be taken } \\
\text { for neighborhood }\end{array}$ & $\begin{array}{l}\text { If your answer is yes, what should } \\
\text { be done for improve the } \\
\text { conditions of your neighborhood? }\end{array}$ & $\begin{array}{l}\text { Close-ended } \\
\text { Question }\end{array}$ \\
\hline $\begin{array}{l}\text { E3. Functions to be } \\
\text { had after regeneration }\end{array}$ & $\begin{array}{l}\text { What kind of functions do you want to } \\
\text { have after possible regeneration project? }\end{array}$ & $\begin{array}{l}\text { Close-ended } \\
\text { Question }\end{array}$ \\
\hline $\begin{array}{l}\text { E4. Dealing with } \\
\text { physical problems }\end{array}$ & $\begin{array}{l}\text { Do you think that a possible } \\
\text { regeneration project deals with the } \\
\text { physical problems of your neighborhood? }\end{array}$ & Yes-No Question \\
\hline $\begin{array}{l}\text { E5. Dealing with } \\
\text { social problems }\end{array}$ & $\begin{array}{c}\text { Do you think that a possible regeneration } \\
\text { project deals with the social } \\
\text { problems of your neighborhood? }\end{array}$ & Yes-No Question \\
\hline $\begin{array}{l}\text { E6. Change of } \\
\text { neighborhood } \\
\text { for socially }\end{array}$ & $\begin{array}{l}\text { Do you think that a possible regeneration } \\
\text { project leads to make the neighborhood } \\
\text { More energetic and liveable? } \\
\text { Do you think that a possible regeneration } \\
\text { project leads a change of } \\
\text { The socio-economic structure? }\end{array}$ & Yes-No Question \\
\hline E7. Real estate prices & $\begin{array}{c}\text { Do you think that a possible regeneration } \\
\text { project leads an increase of real estate prices? }\end{array}$ & Yes-No Question \\
\hline $\begin{array}{l}\text { E8. The future of the } \\
\text { environment }\end{array}$ & $\begin{array}{l}\text { What do you think about the future } \\
\text { of your neighborhood? It will be.. }\end{array}$ & Likert Scale (1 - 5) \\
\hline
\end{tabular}




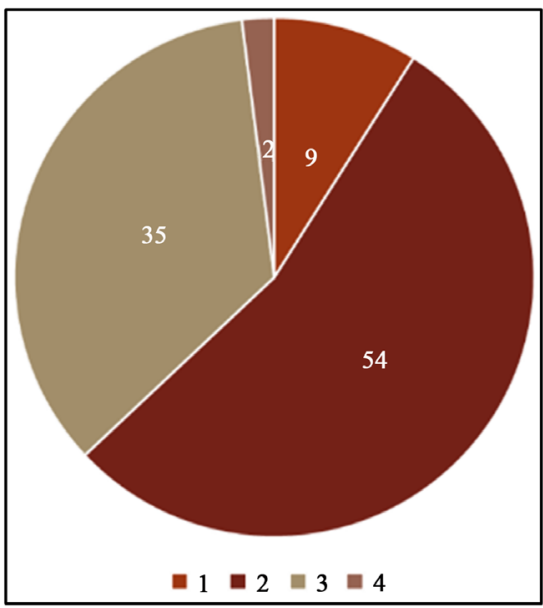

(a)

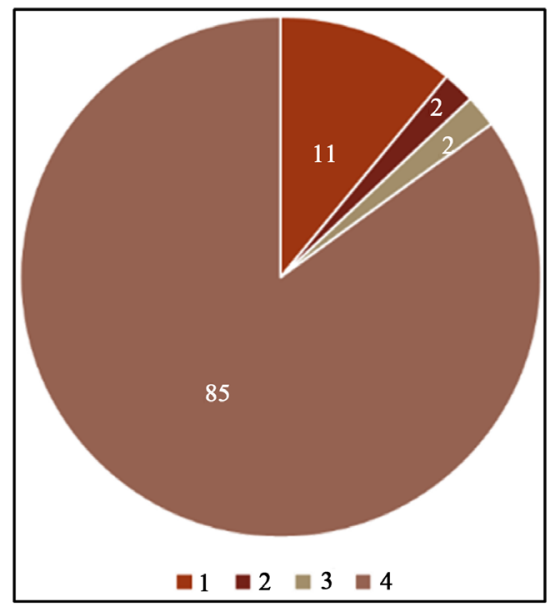

(b)

Graph 7. (a) Responses for "if your answer is yes, what should be done for improve the conditions of your neighborhood?"; (b) Responses for "what kind of functions do you want to have after possible regeneration project?"

Following to this question, it was asked "what kind of functions do you want to have after possible regeneration project?" and they were responsible for four answers to select: 1) shopping malls and entertainment facilities; 2) cultural and educational facilities; 3) business center; 4) open spaces; 5) dwelling units. As it can be seen in Graph 7(b), 85\% of responses shows the residents want to have new dwelling units, and $11 \%$ of participants prefers to have shopping malls and entertainment facilities.

When it was asked that a possible regeneration project can deal with the physical problems of neighborhood or not, $85 \%$ of participants mentioned "yes", and 5\% said "maybe". However, one of the participants saying "no" explains the situation like that "there was not any improvement for our neighborhood after the surrounding project were finished. On the contrary, they caused noise pollution, traffic problem, construction waste pollution and population increase. That's why the conditions of neighborhood got worse".

In a similar way, when it was asked that a possible regeneration project can deal with the social problems of neighborhood or not, $76 \%$ of participants mentioned "yes", and 9\% said "maybe". One of the participants saying YES added that, "after finishing the possible regeneration project, most of the current residents will leave, so social profile will change in the neighborhood. That's why the social problems like robbery, kidnapping or harassment will run out. On the other hand, new projects are generally like gated communities and they have their own security, this will be the another solution for social problems"

The next question was "do you think that a possible regeneration project leads to make the neighborhood more energetic and liveable?". 70\% of participants said "yes", 15\% said "no" and 15\% said "maybe". According to the responses of other question, $80 \%$ of them think that a possible project leads a change of the socio-economic structure in neighborhood. They mention most of the current 
participants leave from the neighborhood.

When it was asked "do you think that a possible regeneration project leads an increase of real estate prices?", as it can be seen in Graph 8(a), $92 \%$ of them said "yes".

One of the participants saying YES claims that, "this neighborhood has already had good prices, it will increase in value after a project"; the other participant saying NO claims that, "this neighborhood had speculative prices at highest rank now, it will not change anymore."

The focal point of these two opinions is that the prices increased (doubled) only after urban regeneration discourses in the neighborhood.

And finally, it was asked that they think the neighborhood will be worse or better in future. They were responsible for selecting a number as a response: 1 (the worst); 2 (worse); 3 (same); 4 (better); 5 (the best).

As it can be seen in Graph 8(b), 93\% of them said it will be the best. One of the participants claims that, "although Atasehir is a new developing area, it has traffic problems because of the high population. The region cannot satisfy the needs of high population. Maybe 5 years later, the quality of economy or physical environment will be better, but this does not mean people living here will have high quality of life. The region will be denser and high density will cause new problems in here".

The responses show that the residents believe in the necessity of new dwelling units in a regeneration project for Barbaros, and they need to be demolished all buildings to build new ones. A possible regeneration project can deal with physical and social problems from their perspective, but not because of the benefits of projects, it is because of the type of the project like gated communities. And it is because of the modificatory social structure, rich people shortly. They ambitiously expect to increase in land and housing prices and that's why they mostly trust in the future to be the best one economically according to their opinion.

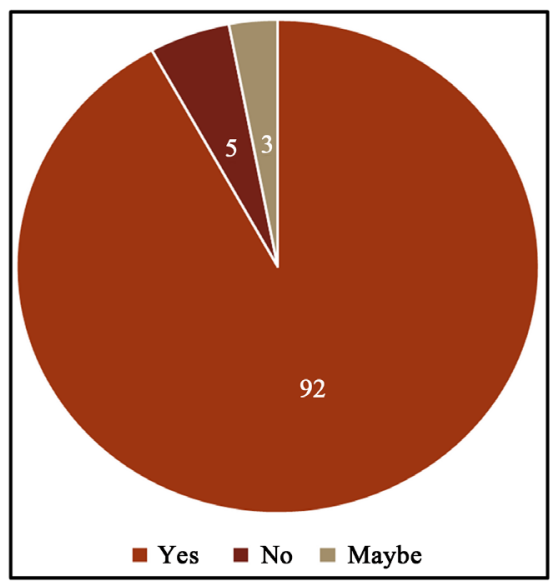

(a)

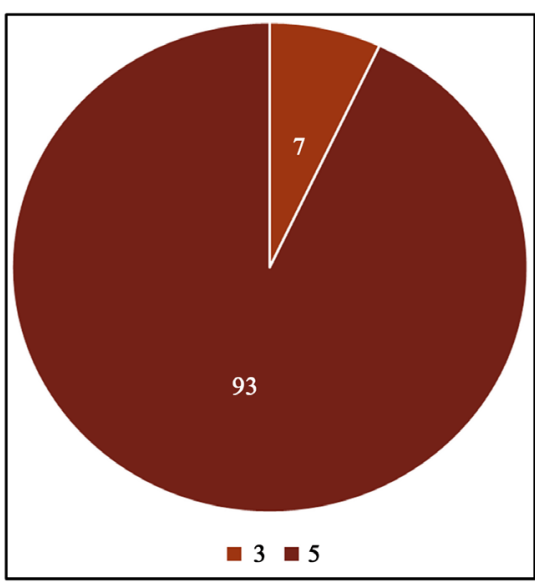

(b)

Graph 8. (a) Responses for "do you think that a possible regeneration project leads an increase of real estate prices?"; (b) Responses for "what do you think about the future of your neighborhood? it will be...”. 


\section{Discussion and Significance of Research}

In Turkey, urban regeneration has gained a new definition with the law of 6306 aiming renovation of risky buildings to have more earthquake resistant neighborhoods in 2012. Although it should be like a tool for urban planning, it has become a method for planning the cities. Moreover, it has been seen as the way of making economic profit not only by investors and local governments day by day.

At the beginning of this research, it was advocated that the current residents of these neighborhoods are the most important stakeholders, and their feelings, perceptions and expectations from regeneration projects are more crucial than the earnings of investors or land developers.

However, there are 3 main conclusions inferred from this research. All participants evaluate themselves as different from potential customers of new projects by saying: "we" and "they". They are mostly not a complainant about displacement because displacement and urban regeneration means new, expensive buildings and a new income channel for them. The residents are mostly interested in economic benefits of urban regeneration projects like land developers and investors.

Barbaros Neighborhood is very important example representing that how real estate projects domineer the neighborhoods for urban regeneration by land developers and investors. Moreover, the research shows how current residents of neighborhoods steer easily by economic speculations and benefits. It is obvious that the adopted urban regeneration projects in Istanbul are like tools neither for having high quality social and physical environments nor earthquake mitigation. They are tools to build luxurious blocks for selling in good prices and they gain favor just for 2 stakeholders; investors and land owners (current residents).

It is realized that residents are not the most important stakeholders in an urban regeneration projects at the end of the research. If the key issue is having better cities, the other city-dwellers should be a stakeholder economically, physically and socially. Every segment of society should have some benefits equally, otherwise, there will be social injustice in society.

This research is a kind of exclamation for decision-makers, legislators and government officials.

\section{References}

2981 Anti-Squatting Law, 1984. R.G.: 18335.

2985 Mass Housing Law, 1984. R.G.: 18344.

5747 (2008). Buyuksehir Belediyesi Sınırları İcerisinde İlce Kurulması Ve Bazı Kanunlarda Degisiklik Yapılması Hakkında Kanun. [Law of Establishment of districts within the boundaries of Buyuksehir Municipality and Changings on some Laws.] R.G.: 26824.

6306 (2012). Afet Riski Altındaki Alanların Donusturulmesi Hakkında Kanun. [Law on Transformation of Disaster Risk Areas.] R.G.: 28309.

Akkar, M. Z. (2006). Kentsel Donusum Uzerine Batı'daki Kavramlar, Tanımlar, Surecler 
ve Turkiye. Planlama Dergisi. [Concepts, Definitions, Processes in Urban Transformation and Turkiye. Journal of Planning.] Ankara: Orta Dogu Teknik Universitesi Sehir ve Bolge Planlama Bolumu.

Aydınlı, H. İ., \& Turan, H. (2012). Kuramsal ve Yasal Cercevede Turkiye'de Kentsel Donusum. [Urban Transformation In Turkey In Theoretical And Legal Context.] Sosyal Bilimler Enstitusu Dergisi. Konya: Selcuk Universitesi.

Donnison, D. (1993). The Challenge of Urban Regeneration for Community Development. Community Development Journal, 28, 293.

Erna, L. (2009). Ístanbul Kentsel Gelisim Alanlarında Ust-Orta ve Ust Gelir Grubu Konut Fiyatlarına Etki Eden Faktorler. Yayımlanmamıs Yuksek Lisans Tezi. [Factors Affecting Housing Prices in the Urban Development Areas of Istanbul, Upper-Middle and Upper Income Group. Graduate Thesis.] İstanbul: İstanbul Teknik Universitesi Fen Bilimleri Enstitusu.

Lichfield, D. (1992). Urban Regeneration for the 1990's. London: London Planning Advisory Committee.

Okumus, D. E. (2014). Kentsel Donusumde Sosyal Donatı Alanlarının Degisimi ve Kentsel Yasam Kalitesine Etkisi: Atasehir Barbaros Mahallesi Ornegi.Yayımlanmamıs Yuksek Lisans Tezi. [The Change of Social Facility Areas in Urban Transformation and Its Impact on Urban Life Quality: Atasehir Barbaros Neighbourhood. Graduate Thesis.] İstanbul: İstanbul Teknik Universitesi Fen Bilimleri Enstitusu.

Osman, M. M., Bachok, S., \& Rabe, N. S. (2014). Local Residents' Perception on Socio-Economic Impact of Iskandar Malaysia: An Example of Urban Regeneration Program in Malaysia. In Asian Conference on Environment-Behaviour Studies (pp. 58-69). Seoul: Chung-Ang University.

Ozcelik, A. D. (2010). En Etkin ve Verimli Kullanım Analizinin Atasehir Orneginde Uygulanması Yayımlanmamıs Yuksek Lisans Tezi. [Implementation of the Most Effective and Efficient Use Analysis in Atasehir Graduate Thesis.] Istanbul: İstanbul Teknik Universitesi Fen Bilimleri Enstitusu.

Roberts, P. (2000). The Evolution, Definition and Purpose of Urban Regeneration Urban Regeneration Handbook. London: SAGE Publications.

Rogers R. (1994). Cultural Policy and Urban Regeneration: The West European Experience. Manchester: Manchester University Press.

Sokmen, P. (2003). Kentsel Donusum Ícin Kaynak Yaratıcı Surdurulebilir Bir Planlama Cercevesi, TMMOB Sehir Plancıları Odası Kentsel Donusum Sempozyumu. [A Planning Framework for Sustainable Resource Creation for Urban Transformation, Urban Transformation Symposium TMMOB Chamber of Urban Planner.] İstanbul: Yıldız Teknik Universitesi.

Tsenkova, S. (2002). Urban regeneration: Learning from the British Experience. In S. Tsenkova (Ed.), Urban Regeneration: Learning from the British Experience. Canada: National Library of Canada Cataloguing.

URL-1 Online Source: http://sehirharitasi.ibb.gov.tr/. Ref. Date: 4.1.2016

URL-2 Online Source: http://emlakgazetesi.com/wp-content/uploads/atasehir2.jpg. Ref. Date: 4.1 .2016 